\title{
Visual Narrative Analysis of Earthquake Prediction in Palelindon Paintings with Wayang Kamasan Styleat Bale Kertha Gosa Klungkung
}

\author{
I Wayan Agus Eka Cahyadi* \\ Faculty of Arts and Design, Institut Seni Indonesia Denpasar \\ Nusa Indah Street Denpasar, 80235, Indonesia \\ E-mail: ekacahyadi@isi-dps.ac.id \\ I Wayan Adnyana \\ Faculty of Arts and Design, Institut Seni Indonesia Denpasar \\ Nusa Indah Street Denpasar, 80235, Indonesia \\ E-mail: kun adnyana@yahoo.com
}

\begin{abstract}
Palelindon's painting at Bale Kertha Gosa Klungkung is a narrative painting that illustrates the prediction of the effects of earthquakes according to lunar calculations (sasih). This Palelindon painting with Wayang Kamasan style is found on the ceiling of the Bale Kertha Gosa building, a building from the Klungkung kingdom. This research aims to explain the visual narrative of Palelindon's paintings on the ceiling of Bale Kertha Gosa Klungkung. The sresearch was conducted at Bale Kertha Gosa in Klungkung Regency. Data was collected through field observations and literature study. The findings of this research is the visual narrative of Palelindon paintings with Wayang Kamasan style arranged in 12 scene themes. Each scene shows a god who is doing yoga, accompanied by several human, animal and plant characters who narrate a condition or prediction of an earthquake in a sasih. The scene of sasih kasa (first) is located on the north side of the middle, moving around in a clockwise direction (Pradaksina).
\end{abstract}

Keywords: Palelindon, Kertha Gosa, earthquakes, Kamasan

DOI: $10.7176 / \mathrm{ADS} / 99-02$

Publication date: February $28^{\text {th }} 2022$

\section{Introduction}

Bali is an island located in the Pacific Ring of Fire, an area around the Pacific Ocean where several tectonic plates meet, which are prone to earthquake. Earthquake in Balinese terms is called "linuh/lindu". Myth in Bali about earthquake mentions the existence of a giant tortoise (Bedawangnala) that is entangled by two dragons, the dragon Basuki and the dragon Anantaboga as the earth support. The movement of this giant tortoise is considered a trigger for earthquakes. Earthquake will have an impact on building damage and tsunami and often cause fatalities. But on the other side the earthquake is also seen as a sign of nature to read and predict human life.

Lontar Roga Sanghara Bumi explains the signs and characteristics of nature that can bring good or bad to human life, one of which is by observing the occurrence of earthquakes according to the calculation of the moon or sasih (Paramita, 2018; 41). This knowledge is known as Palelindon. Palelindon is a prediction based on understanding of the incident of earthquake or vibrations in the human body and their good and bad impacts on life (Suarka, 2016: 2). With this knowledge, the Balinese get an explanation of the effects of earthquakes on their life according to sasih or month calculations based on the Saka calendar. Like the eruption of Mount Agung in 1963 (Reid, 2005: 65), which caused an earthquake in Sasih Kaulu (the eighth month) is believed to be a bad sign. It is said that there will be a lot of chaos, people were not calm, etc. This was later linked to the riots and killings in Bali in 1965 against sympathizers of the Indonesian Communist Party. Palelindon knowledge is written in the lontar media (lontar Roga Sanghara Bhumi) which is written in Balinese script and in Kawi language. In Bale Kertha Gosa this knowledge is illustrated in the form of a narrative painting with Wayang Kamasan style that is placed on the ceiling of the building.

Bale Kertha Gosa is a heritage building of the Klungkung Kingdom. Kertha Gosa is estimated to have been built in the 17th century along with the construction of Puri Semarapura which was built to replace the center of the Balinese kingdom which was previously located in Gelgel. When the puputan Klungkung occurred which marked the end of the royal period in Bali, Bale Kertha Gosa became one of the buildings of Puri Semarapura that escaped destruction. Apart from Kertha Gosa, the remains of Puri Semarapura that we can still see today are the Bale Kambang and Pemedal Agung buildings. The painting of Palelindon Wayang Kamasan at Bale Kertha Gosa has undergone several repairs. Repairs began in 1918 (probably due to the impact of the 1917 earthquake). In 1933 the fabric media was replaced with asbestos board material. In 1963 a number of paintings were replaced. 
Finally in the 1980s a number of damaged images were replaced with new images (Vickers, 2012; 77).

The visual narration of the Palelindon painting with Wayang Kamasan style at Bale Kertha Gosa is very valuable and important to study. This painting is an attraction for tourists to visit Bali. Visitors are fascinated by the existence of this painting, but very few are able to read and understand the story and message contained in the painting. It requires an understanding of the concepts of visual communication in the Wayang Kamasan painting (Mudana, 2016; 205). The painting on the ceiling of the Bale Kertha Gosa building has a role as a medium to communicate messages visually. Message delivery through the involvement of illustrations as an element of visual stimulation, of course, can produce an interactivity value (Julianto \& Cahyadi, 2020: 597). A number of researchers have researched the paintings in Bale Kertha Gosa, but no one has ever done anything about the visual narration of the palelindon painting on the ceiling of the Bale Kertha Gosa building.

The purpose of this research is to determine the visual narration of Palelindon painted in the Wayang Kamasan style and to find out the method of reading the Palelindon images found on the ceiling of the Bale Kertha Gosa building.

\section{Research Methods}

The research is conducted at Bale Kertha Gosa in Taman Gili area, the heritage of Puri or the royal palace of Semarapura-Klungkung in Klungkung Regency. Data was collected through field observations and literature study. Field observations were carried out to obtain visual data regarding the Palelindon images in the Bale Kertha Gosa building, Taman Gili Klungkung. This visual data is identified to classify the type of diversity of the Palelindon images. Meanwhile, data collection through literature study is intended to obtain several theories and approaches in analyzing and solving research problems.

As qualitative research, the analysis of the research also uses qualitative analysis with the following details: first, the data that has been collected are grouped and identified to provide an explanation of the elements in the Palelindon images. Second, to analyze the method of reading Palelindon images found on the ceiling of the Bale Kertha Gosa building

\section{Analysis And Data Interpretation}

Bale Kertha Gosa Klungkung is one of the buildings of the Semarapura kingdom that escaped damage during the Puputan Klungkung war in 1908. This war occurred as a result of the Dutch invasion of the Klungkung kingdom. Before being conquered by the Dutch, the kingdom of Semarapura Klungkung was the most influential kingdom in Bali. Dewa Agung, the king of Klungkung, also the lord of Bali and Lombok, was a leader who had great influence not only on the island of Bali but also on the island of Lombok. This kingdom inherited the glory of the Gelgel kingdom which reached its peak under the reign of king Dalem Waturenggong in the 14th century. Puri Suwecapura in Gelgel was damaged by the rebellion in 1651-1686 during the reign of Dalem Di Made. Then one of his children, Dewagung Jambe, managed to reclaim the city of Gelgel. However, because it was damaged, it was decided to move the royal capital to Klungkung (Agung, 1989: 23). So a new castle or palace was built in Klungkung with the name Puri Semarapura in 1622 Caka or 1700 AD. It is estimated that at this time the Bale Kertha Gosa building was built.

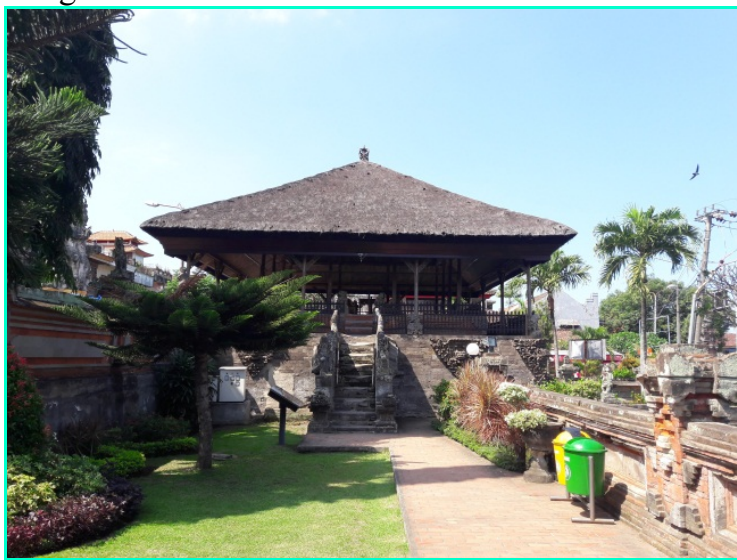

Figure 1. Kertha Gosa Hall, a legacy of Puri Semarapura Klungkung (source: Cahyadi, 2019)

Referring to the floor plan of Puri Semarapura Klungkung, Bale Kertha Gosa is in the northeast of Puri Semarapura (Geertz, 1979; 110). It is located in the same area as Bale Kambang, known as the Taman Gili area. This area is a very sacred place in Puri Semarapura. In royal time, Bale Kertha Gosa was used as a meeting place for the king of Klungkung with subordinate kings throughout Bali, as well as a place to receive royal guests from outside Bali. In this hall, the king usually gives directions and conveys decisions regarding policy towards the 
Balinese kingdom. During the Dutch administration, this hall functioned as a customary court, where all litigants were tried and sentenced here (Pucci, 1992; 17).

On the ceiling of the Kertha Gosa hall, a narrative painting in the style of Wayang Kamasan is attached. Wayang Kamasan is drawing tradition of wayang style that developed in the village of Kamasan. This tradition has existed and developed rapidly during the Gelgel kingdom and the Klungkung kingdom. Wayang Kamasan has a very strong style and grip. The shape and composition of wayang kamasan resembles the narrative reliefs on temple buildings and wayang berber paintings that developed during the Majapahit kingdom in East Java. It narrates themes originating from literary works such as Mahabaratha story, Ramayana, Tantri, Panji and astronomical knowledge. Wayang Kamasan is also considered to have a close relationship with wong- wongan and rerajahan images which have religious and spiritual meanings.

The image of the wayang Kamasan in the Kertha Gosa hall displays a number of story themes such as the story of Tantri, Bima Swarga, Garuda and Palelindon knowledge. The Palelindon theme is a theme that does not come from stories but from knowledge about the prediction of earthquake incidents.

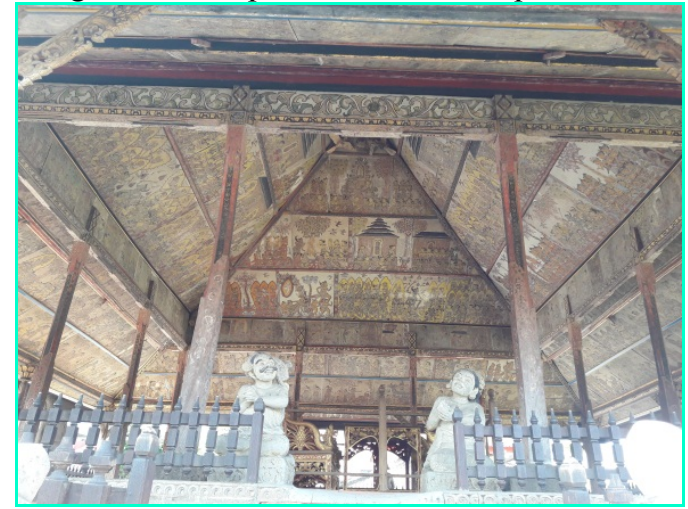

Figure 2. The image of the Wayang Kamasan on the ceiling of the Kertha Gosa hall Klungkung (source: Cahyadi, 2019)

Palelindon knowledge at Bale Kertha Gosa is presented in narrative images. There are a number of scenes arranged in several panels, lined up lengthwise round the ceiling of the building. Each scene is built by appearing a number of characters complemented by other iconic recognizable elements. The characters and elements in Palelindon's drawings include the characters of gods, humans, animals, trees, and a number of elements of everyday equipment.

The character of a god can be recognized by the appearance of a body shape like the shape of a human body, with a "sweet", "giant" and "hard" face. The adornment corresponds to the nature and position, and the body emits golden rays. The character of the god is shown by sitting or doing yoga on a vehicle or seat in the form of lotus flowers, peacocks, etc. In front of the embodiment of this god there is a text or writing that provides information about the month or sasih, the name of the god who does yoga and an explanation of the impact of the earthquake that occurred on that sasih.

Humans are depicted with everyday clothes that refer to the type of work and status. As a person who works in the fields (farmers) is shown wearing a conical hat or capil without clothes and or wearing clothes and wearing kamben or cloth above the knee equipped with agricultural tools such as sickles, hoes etc. Merchants, usually a woman who is shown shirtless, wearing a kamben or cloth and equipped with goods. Dancers are shown demonstrating dance moves, wearing flower arrangements on their heads and waving hand fans accompanied by male dancer who are also dancing. Penabuh or gamelan players are equipped with a set of gamelan and drums. Aristocracy or leaders are shown with headdresses that resemble the shape of a gelungan that resembles the attributes of wayang panji (a form of wayang that tells the story of panji), wears no clothes, and is usually shown carrying a keris in a battle scene. Children are shown with a smaller body size without wearing clothes.

Animals are depicted in the Wayang Kamasan style referring to the forms of animals that exist in nature, such as rats, dogs, buffalo, centipedes etc. Animals which in fact have a small size are shown with a larger size, so that it is easy to be identified.

Plants are displayed in an iconic way that is easy to be recognized. Types of plants can be identified from the shape of the leaves, flowers, and fruit. The presence of plant in each scene is to strengthen the atmosphere and describe the environmental conditions. The atmosphere of the night can be recognized by the presence of stars depicted in the form of spheres with the emittance of rays around them and the moon in the form of a white crescent moon side by side with the stars.

The images of Palelindon in Bale Kertha Gosa lined up round the top of Bale Kertha Gosa, in the fifth row from the bottom, after the theme of the Tantri story and Bhima Swarga in the second and third row and the theme 
of the Garuda story in the fourth row. The images of Palelindon illustrates a number of scenes according to the sasih calendar. Sasih calendar is a system of calculating months in the Balinese calendar or the Caka calendar. This system in one year consists of 12 months, namely: (1) Kasa, July-August; (2) Karo, August-September; (3) Third or Katelu, September-October; (4) Kapat, October-November; (5)Kelima, November-December; (6) Kenem, December-January; (7) Kepitu, January-February; (8) Kaulu, February-March; (9) Kesanga, MarchApril; (10 )Kedasa, April May; (11) Jiyestha, May-June; and (12) Sadha, June-July. The lunar cycle or sasih of the Caka calendar lasts for 29.5 days which is different from the Gregorian calendar calculation (Soedarsono, 1999: 29). After knowing about the sasih calculation system, then we can search for and read the narration of Palelindon images according to earthquake incidents based on sasih calculations. If the images of Palelindon in Kertha Gosa Klungkung are sorted according to the order of sasih calculations starting from sasih Kasa or the first month in the Saka calendar, then the reading of the Palelindon images starts from the north side of the center.

The image of Palelindon sasih Kasa shows the image of a goddess, namely Dewi Sri who is depicted sitting on a vehicle in the form of a peacock facing to the left. The body of the sakti of Lord Vishnu is seen to be surrounded by the emittance of yellow rays. A number of everyday scenes build the narration of the image of Palelindon sasih kasa, such as the scene of an adult man picking coconuts from the fruitful coconut tree, while a small child is picking up fallen coconuts, and a woman holding up a basket full of coconuts. Another scene shows the atmosphere of buying and selling transactions between traders and buyers. The visualization of this scene narrates a safe and prosperous society. This explains the narration about the effect of the earthquake on sasih Kasa, and the one who does yoga is Dewi Sri, the sakti of Lord Vishnu. This means that the country will be at peace, agriculture and trade will be successful, people will live in prosperity.

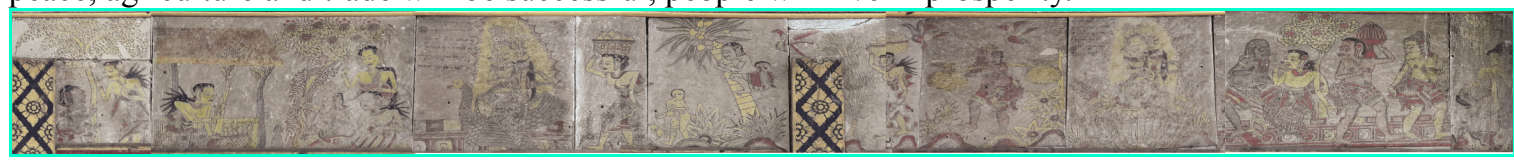

Figure 3. Visual Narration of the Panting of Palelindon Sasih Kasa and Karo

(source: Cahyadi, 2019)

From the north in the center, then moving to the right side, you will meet an image of Palelindon which explains the earthquake that occurred in Sasih Karo or the second month. The image of Palelindon sasih Karo shows a beautiful goddess sitting cross-legged on a lotus flower, in the middle of a pond with the emittance of yellow rays surrounding her body. The figure of this goddess is known as the goddess Ganges, the goddess who rules the Ganges River as the source of the spring of life. A number of scenes are shown, such as the scene of a woman walks with a basket full of crops followed by a man with conical hat carrying two bunches of yellow paddies. Then to the right of Dewi there is a scene of people interacting happily. Flowers bloom and food available in abundance. This image explains about the effects of the earthquake that occurred in Sasih Karo. The one who does yoga is goddess Ganges. So that the country will be orderly with lots of rain and the plants will be fertile.

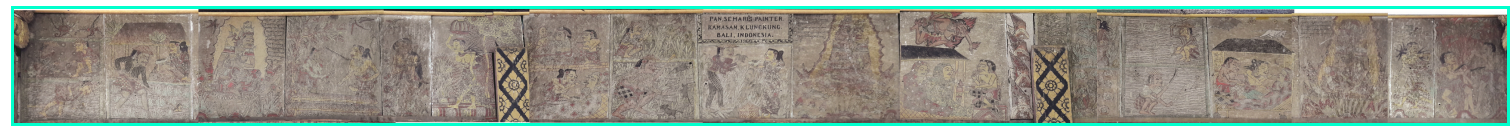

Figure 4. Visual Narration of Palelindon Painting at Bale Kertha Gosa on the East side

(source: Cahyadi, 2019)

Next, move to the images field in the East. This side shows an image of Palelindon according to the three count of sasih, namely Sasih Katelu, Kapat and Kalima. Starting from the left is Palelindon sasih Katelu. The images show Lord Vishnu doing yoga on a lotus flower facing to the right and scenes of farmers who are actively working to cultivate ricefields that are abundant with water, assisted by women who prepare food. Flowers and seeds grow well, and there is a scene of a woman holding up a container (wanci) which usually contains food offerings as a form of gratitude for the gifts that have been received. The god who does yoga during the earthquake that happened in Sasih Katelu is Lord Vishnu, so it rained heavily and the plants full of fruits.

Move to the right we will find an image of Palelindon sasih Kapat. Lord Brahma is depicted doing yoga who is sitting on a lotus flower with a reddish-yellow light emanating from his body. The narration shows scenes of sick people lying limp in bed being fed, young people are smoking opium together, agricultural land being destroyed by birds and rats, the harvest is not good, and two sick people are being treated by a traditional healer or balian, but on the roof of their house appears a supernatural being who does black magic who has transformed into a "leak". This illustrates that if an earthquake occurs in Sasih Kapat, there will be many disease outbreaks, and pests occur everywhere, the country is not safe and full of disasters.

On the East side on the far right is Palelindon sasih Kalima. It shows the image of god Iswara who is doing yoga on a lotus flower. It also shows the scenes of farmers who are busy getting rid of rats and grasshoppers that disturb their crops. There is also a person lying limp at home being fed and visited by balian, and on the roof of 
his house there is a white monkey peeking which in Balinese belief is considered a fake monkey that cause the person to get sick. On the other hand, two people unsheathe their swords to fight under a large tree with red leaves. This provides information that the god who does yoga in the earthquake in Sasih Kalima was Bhatara Iswara, as a result the country would be shaken. There would be many disease outbreaks and many pests destroy crops so that the country is not safe and prone to disputes.

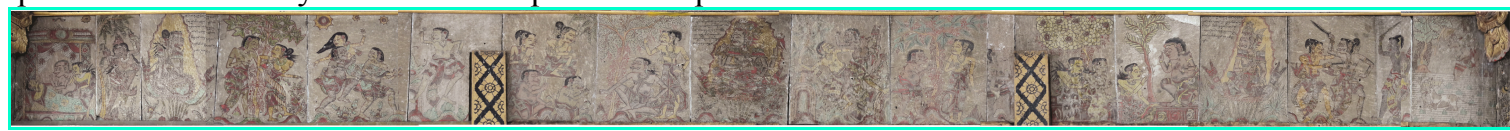

Figure 5. Visual Narration of Palelindon Painting at Bale Kertha Gosa on the South side (source: Cahyadi, 2019)

Move to the south side, the image describes the impact of the earthquake that occurred on Sasih Kenem, Kapitu and Kaulu. The one who does yoga in Sasih Kenem is Dewi Durga who resides in the Prajapati temple or the grave temple. There are a number of scenes showing a hazardous atmosphere. There are kidnappings of women at night. There are people who are sick because of black magic. This confirms that the earthquake in Sasih Kenem and the one who doed yoga is goddess Durga means that the country suffers and there are many disease outbreaks. The one who does yoga in Sasih Kapitu is Bhatara Guru, a four-handed god who is surrounded by emittance of rays. A number of scenes are shown such as scenes filled with chaos, fight scenes, tensions between leaders. The god who does yoga during the earthquake that happen in Sasih Kapitu is Bhatara Guru which means that the country is not safe, the people are confused, so there is chaos.

The god who is doing yoga during the earthquake in Sasih Kaulu is Bhatara Parameswara. He sits on a lotus flower facing to the left. The image shows scenes that are prone to fights. People draw swords at each other to fight and many rats are found. This gives information that the earthquake in this Sasih has resulted in people's heart are not calm and must be careful because there are many conflicts.

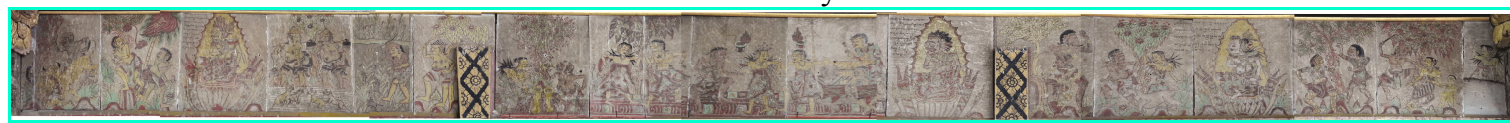

Figure 6. Visual Narration of Palelindon Painting at Bale Kertha Gosa on the West side

(source: Cahyadi, 2019)

Move to the west side which shows the image of Palelindon sasih Kesanga, sasih Kedasa and sasih Jesta. The image of Palelindon sasih Kesanga shows Batara Rama who is doing yoga on a lotus flower facing left. The scenes show coconut trees burning in flames, perhaps due to being struck by lightning which indicates unfriendly weather. Farmers hunt the rat pests that damage rice and corn crops. So, if an earthquake occurs in this Sasih, and the one who does yoga is Batara Rama, then the people will suffer from natural disasters and calamities. The image of Palelindon sasih Kedasa shows the god Narashinga who is doing yoga on a lotus flower facing to the left with his body surrounded by reddish yellow light. The scene that accompanies the lion-headed deity is a scene filled with joy, such as men enjoy drinks, the meeting of men and women, the performances of joged and pengibing accompanied by gambelan at a resin-lit night. This indicates that an earthquake happened in Sasih Kedasa and Bhatara Narashinga who does yoga would make the country is safe and peaceful and the people live happily.

The image of Palelindon sasih Jesta shows white god Sambhu sits on a lotus flower with the radiance of sacred yellow rays. It also shows tense scenes. Dogs bite their master's legs, fights in the household between brothers and sisters, as well as husband and wife violence witnessed by small children. If there is an earthquake in sasih Jesta, and Bathara Sambhu does yoga, the country will be damaged, the country is not safe and there will be frequent conflict and violence.

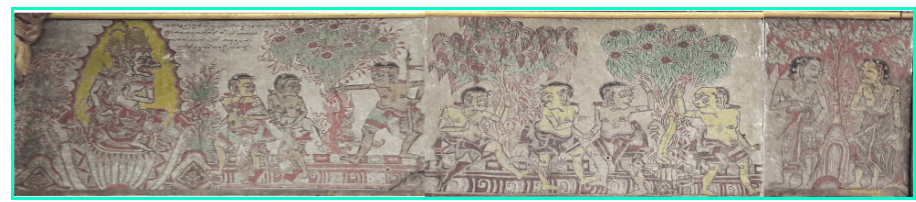

Figure 7. Image of Palelindon sasih Sadha

(source: Cahyadi, 2019)

Image of Palelindon Sasih Sadha or the twelfth month is in the northern part of the left side. It Shows the god or bathara Anantaboga, the dragon-headed deity who is doing yoga on a lotus flower facing to the right accompanied by scenes of fighting over farm animals, many venomous animals appear that bite humans. The earthquake in this $\mathrm{Sasih}$ can cause a lot of riots and the country is not safe.

\section{Conclusion}

Palelindon knowledge on the ceiling of Bale Kertha Gosa is visualized in the Wayang Kamasan style which refers to the concept of Tri Hita Karana, narrate the strong relationship between parayangan, pawongan and 
palemahan. Parahyangan as the world of the Gods is expressed by the appearance of various manifestations of the gods who are depicted sitting doing yoga on a lotus flower and a peacock. Pawongan and palemahan are represented by the appearance of human characters in various social and professional levels, as well as the natural environment (animals and plants) in a narration that explains a number of conditions (good or bad) that humans may experience as a result of an earthquake in certain sasih.

Reading the image of Palelindon Wayang Kamasan on the ceiling of the Bale Kertha Gosa building is based on the Pradaksina concept, which rotates from left to right in a clockwise direction. If it refers to the sequence of first sasih (Kasa) and so on, then the reading can be started from the North side of the center. Then in each of these sasih. the reading begins by recognizing the image of the god visualized in that sasih, then proceeds to read the accompanying narration.

\section{References}

Agung, Ide Anak Agung Gde. (1989). Bali Pada Abad XIX: Perjuangan Rakyat dan Raja-Raja Menentang Kolonialisme Belanda. Yogyakarta: Gajah Mada University Press.

Geertz, Clifford. (1979). Negara: The Theatre State in Nineteenth Century Bali. Princeton: Princeton University Press.

Julianto, I. N. L., \& Cahyadi, I. W. A. E. (2020). Interaktivitas Ilustrasi pada Ruang Belajar Siswa SD Kelas 1-3 di Bali. Panggung, 30(4).

Mudana, I Wayan, Pande Ketut Ribek. (2017). "Komodifikasi Seni Lukis Wayang Kamasan sebagai Produk Industri Kreatif Penunjang Pariwisata". Jurnal Mudra, 32 (1)

Paramita, I Gusti Agung. (2018). Bencana, Agama dan Kearifan Lokal. Jurnal Dharmasmrti, 18 (1).

Pucci, Idanna. (1992). Bhima Swarga: The Balinese Journey of the Soul. New York USA: Bulfinch Pr.

Reid, Anthony. (2005). History and Seismology in the Ring of Fire Punctuating the Indonesian Past, dalam David Henley dan Henk Schulte Nordholt ed. Environment, Trade and Society in Southeast Asia: A Longue Duree Perspective. Leiden: Brill.

Soedarsono, R.M. (1999). Metode Penelitian Seni Pertunjukan dan Seni Rupa. Bandung: Masyarakat Seni Pertunjukan Indonesia.

Suarka, I Nyoman. (2016). Ramalan dalam Perspektif Budaya Bali. Makalah Seminar Nasional Bertema "Ramalan dan Kehidupannya", diselenggarakan oleh Keluarga Mahasiswa Sastra Nusantara (KAMASUTRA) Bekerjasama dengan Prodi Sastra Jawa, Departemen Bahasa dan Sastra, Fakultas Ilmu Budaya, Universitas Gadjah Mada, Yogyakarta.

Vickers, Adrian. (2012). Balinese Art: Painting and Drawings of Bali 1800-2010. Singapore: Tuttle Publising.

Vickers, A. (1990). Balinese Texts and Historiography. History and Theory, 29(2). https://doi.org/10.2307/2505223

First Author is a Lecturer in Study Program of Visual Communication Design at Indonesian Art Institute Denpasar, (2010-present). I completed my undergraduate program (S.Sn) in study program of Fine Arts at the Indonesian Institute of the Arts Yogyakarta in 2007. Then I completed my postgraduate program (M.A) at Gajah Mada University in 2010, in the Study Program of Art Studies. From 2018-now, I am studying in doctoral program (Dr.) at Indonesian Art Institute Denpasar, Study Program of Science of Art.

Second Author is a Lecturer of Study Program of Fine Art at Indonesian Art Institute Denpasar (2003-present). I finished my Bachelor Degree (S.Sn) in the Study Program of Fine Art at the STSI Denpasar (1997-2002). Then completed my Master's Degree (M.Sn) at the Indonesian Institute of the Arts Yogyakarta (2006-2008), in Study Program of Art Studies. Since 2011-2015, I completed my Doctoral Degree (Dr.) at the Indonesian Institute of the Arts Yogyakarta, in the Study Program of Fine Arts Studies. 